\title{
First report of Neoramularia bidentis for Ukraine and notes on several rare Ramularia species (Ascomycota)
}

\author{
Tetiana V. ANDRIANOVA \\ M.G. Kholodny Institute of Botany, National Academy of Sciences of Ukraine \\ 2 Tereshchenkivska Str., Kyiv 01004, Ukraine \\ tand@darwin.relc.com
}

Andrianova T.V. 2020. First report of Neoramularia bidentis for Ukraine and notes on several rare Ramularia species (Ascomycota). Ukrainian Botanical Journal, 77(1): 3-15.

Abstract. Several noteworthy species of the genera Neoramularia and Ramularia (Mycosphaerellaceae) were recorded in August 2018 in the territory of Prypyat'-Stokhid National Nature Park (Volyn Region, Liubeshiv District, Ukraine). Neoramularia bidentis, a species so far only known from South Korea and Poland, was collected on withering leaves of Bidens frondosa (a new host species). Ramularia crepidis on Crepis tectorum was recorded only for the second time in Ukraine since the $1950^{\text {th }}$ and $R$. gnaphalii was found on a new host plant, Laphangium luteoalbum. The latter species was so far known from Ukraine only on Omalotheca sylvatica (Gnaphalium sylvaticum) and Gnaphalium uliginosum from Kyiv Region collected about 45 years ago. The plant pathogenic fungus R. lysimachiae on leaves of Lysimachia vulgaris was found to be abundant in Volyn Region. All species are described, illustrated with original scanning electron microscope micrographs, supplemented with host range, distribution data and comments.

Keywords: Bidens, Crepis, fungi, Gnaphalium, Lysimachia, morphology, Mycosphaerellaceae, plant pathogens, Volyn Region

Submitted 15 April 2019. Published 28 February 2020

Андріанова Т.В. 2020. Перша знахідка Neoramularia bidentis в Україні та нотатки щодо деяких рідкісних видів Ramularia (Ascomycota). Український ботанічний журнал, 77(1): 3-15.

Інститут ботаніки ім. М.Г. Холодного НАН України

вул. Терещенківська 2, Київ 01004, Україна

Реферат. На території Національного природного парку "Прип'ять-Стохід" (Волинська обл., Любешівський р-н, Україна) у серпні 2018 року зареєстровано чотири маловідомих види родів Neoramularia i Ramularia (Mycosphaerellaceae). Neoramularia bidentis, до сьогодні відомий лише з Південної Кореї та Польщі, в Україні уперше зібраний на в'ялих листках Bidens frondosa (нова живильна рослина). Ramularia crepidis знайдений вдруге в Україні з 1950-х років, відмічений на Crepis tectorum. Ramularia gnaphalii виявлений на новій живильній рослині - Laphangium luteoalbum; вид був знайдений в Україні на Omalotheca sylvatica (Gnaphalium sylvaticum) і Gnaphalium uliginosum майже 45 років тому і тільки у Київській області. Фітопатогенний вид $R$. lysimachiae зібрано на листках Lysimachia vulgaris, масовий його розвиток відмічено у Волинській області. Всі види проілюстровані оригінальними фотографіями, зробленими за допомогою сканувального електронного мікроскопа, для них надано описи, дані щодо їхнього поширення, наведені живильні рослини.

Ключові слова: Волинська область, гриби, морфологія, патогени рослин, Bidens, Crepis, Gnaphalium, Lysimachia, Mycosphaerellaceae

\footnotetext{
(C) 2020 T.V. Andrianova. Published by the M.G. Kholodny Institute of Botany, NAS of Ukraine. This is an open access article under the terms of the Creative Commons Attribution License (http://creativecommons.org/licenses/by/4.0/), which permits use, distribution, and reproduction in any medium, provided the original work is properly cited
} 


\section{Introduction}

The examination of the diversity of phytopathogenic micromycetes is important as it enables one to estimate the fungal interactions with plants and the environment, as well as to predict changes in ecosystems. The family Mycosphaerellaceae comprises about six thousand species and is amongst the largest groups of Ascomycota. These micromycetes are predominantly plant pathogens that can cause leaf lesions, fading and dying of leaves and whole plants, besides some pathogens of fungi, endophytes and saprotrophs (Vasil'evsky, Karakulin, 1937; Tomilin, 1979; Braun, 1998; Videira et al., 2016). The diversity of mycosphaerellaceous fungi is in general huge and still under the investigation in Ukraine. At the same time, fluctuations in climatic factors have led to drier and hotter summer seasons in forest and foreststeppe zones, provoking the migration and invasions of new and rare species of fungi.

\section{Materials and methods}

Infected plants with lesions were collected in the north of Ukraine, on the territory of Prypyat'-Stokhid National Nature Park near Buchyn, Liubyaz', Selisok and Svalovychy villages (Volyn Region, Liubeshiv District) in August 2018. This protected area is a part of the Ukrainian Polissya (Western Polissya) and stretches along the Prypyat' River and a part of its tributary, the Stokhid River.

The fungal specimens were examined under a dissecting microscope (DM) and by standard light microscopy (LM), finely cut and mounted in water or $5 \%$ aqueous lactic acid solution and $1 \%$ cotton blue in lactophenol, respectively. Samples for scanning electron microscopy (SEM) were coated with a thin layer of gold and palladium by ion beam sputtering coater JFC1100. Images were obtained under the scanning electron microscope JEOL JSM-6060 LA.

Analyses of the general distribution of the studied fungi were based on the data from various bibliographic sources and publications, as well as databases available through the Internet: USDA Fungal Database (Farr, Rossman, 2019) and Mycology Collections Portal (MyCoPortal, 2019).

The specimens are deposited in the Mycological Collection of the M.G. Kholodny Institute of Botany, National Academy of Sciences of Ukraine (KW-M).

\section{Results and discussion}

During the course of field studies in Prypyat'-Stokhid National Nature Park, Neoramularia bidentis Shin \& U. Braun, a fungal species new to Ukraine, was found. This species had been supposed to be allied to the genus Cercospora Fresen. (Shin, Braun, 1993). Recently it is provisionally placed in Ascomycota, Incertae sedis, according the Index Fungorum (Index Fungorum, 2019). The phylogenetic position of $N$. bidentis and the whole genus Neoramularia U.Braun in general is still unknown. Moreover, several noteworthy species of the genus Ramularia Unger (Mycosphaerellaceae, Capnodiales, Ascomycota) were collected in the park as well.

Detailed descriptions and notes on micromorphological characters and the distribution of Neoramularia bidentis, Ramularia crepidis Ellis \& Everh., $R$. gnaphalii (P.Syd.) Karak. and R. lysimachiae Thüm. are provided, supplemented by the photographs of specific symptoms (under the dissecting microscope) and micrographs of morphological structures (under the scanning electron microscope).

\section{Neoramularia bidentis Shin \& U. Braun, Mycotaxon 49: 352. 1993. (Fig. 1)}

On living and fading leaves. Leaf spots oblong to angular, irregular, 2-3 $\mathrm{mm}$ across, brown to hazel, small, scattered and without distinct margins; older lesions dry, irregular, scattered, developing along the veins and limited by main veins, 3-5(-6) $\mathrm{mm}$, tan to brown, with dark brown to reddish brown margins, $0.5 \mathrm{~mm}$ wide, without halo; sometimes older lesions more delicate, parchment-like and depressed in the center of initially infected tissues, lesions on the lower surface of leaf concolorous, with convex, dark brown margins; lesions bearing greyish white or yellowish white caespituli on both sides of the leaves. Mycelium immersed, hyphae colorless, septate, 1-2 $\mu \mathrm{m}$ wide; subepidermal hyphae growing into leaf stomata, bearing outward projecting conidiophores or erumpent through collapsed epidermal cells, single or in small, loose groups, mainly hypophyllous. Conidiophores colorless, cylindrical, $(10-) 12-25(-30) \times 3.5-4.5(-6) \mu \mathrm{m}$, straight or slightly sinuous, smooth, simple or rarely branched, usually with a single septum or unicellular and hence functioning as a conidiogenous cell; with swollen base and slightly tapering toward a rounded apex, provided with slightly papillate scars. Conidiogenous cells colorless, holoblastic, terminal, subcylindrical, showing minimal percurrent enteroblastic proliferation, followed by replacement apical wall-building, collarettes small, 
or sometimes with several sympodial proliferations and inconspicuous conidiogenous loci where conidia have been seceded (scars); conidiogenous loci unthickened (viewed under the LM), slightly prominent, $0.2-0.5(-1.0)$ $\mu \mathrm{m}$ high and $0.8-1.0 \mu \mathrm{m}$ diam., with a collarette where the walls of conidiogenous cell and conidium were joined prior to secession, looking like a rupture of the conidiogenous cell wall, with initially fine crenulated edge or with an involute sinuous edge in older loci, up to $0.2 \mu \mathrm{m}$ wide, forming a shallow central crater (viewed under the SEM). Conidia colorless, solitary or catenate, often in unbranched connected chains, where conidia may also function as conidiogenous cells while still attached, producing further conidia, resulting in long chains of spores; single conidia subcylindrical to cylindrical, fusiform, $12-24(-32) \times 3.0-5.0 \mu \mathrm{m}$, smooth to sparsely verruculose, rough (LM), with sparsely granulate protuberances, $0.1-0.3 \mu \mathrm{m}$ diam. (viewed under the SEM); unicellular or 1-2-septate, not narrower at the septa; apex rounded and minutely tapered at place of conidial junction (terminal hilum), basal end tapered and truncate; hila (scars) inconspicuous or raised up to $0.1-0.2 \mu \mathrm{m}$ (SEM).

Distribution in Ukraine. On living and withering leaves of Bidens frondosa L.: Volyn Region, Liubeshiv District, Prypyat'-Stokhid National Nature Park, Svalovychy village, 51 $52^{\prime} \mathrm{N}, 2^{\circ} 38^{\prime} \mathrm{E}$, Svalovychy wood plot, Spalenyi Mist parcel, Alnus glutinosa (L.) Gaertn. forest, beside a runnel, August 14, 2018, T.V. Andrianova; KW-M71185.

General list of host plants. Bidens tripartita L. (type host), B. frondosa L. (new host reported here) (Asteraceae).

General geographical distribution. Asia: South Korea. Europe: Poland, Ukraine.

Notes. New to Ukraine.

The fungus Neoramularia bidentis was described on Bidens tripartita L. from Asia, South Korea (Shin, Braun, 1996) and found in various localities of this country (Kim, Shin, 1999). The species was collected on the same host plant in Poland about a decade later (Ruszkiewicz-Michalska, Wołczańska, 2008). Observed short conidiophores and catenate conidia of $N$. bidentis in the Polish specimens were similar to characteristics of reproduction structures in the Korean ones, and the finding was supported by one of the species authors, U. Braun. Since then this fungus has not been observed in other countries and on other host plants of the genus Bidens L.
In a recent survey of more than 80 pathogens invading cosmopolitan weeds $B$. pilosa L. and B. subalternans DC., $N$. bidentis has not been discovered amongst them (Guatimosim et al., 2015).

Collected specimens of this species on B. frondosa (an alien species of North American origin) in Ukraine are morphologically similar to the descriptions and drawings in Shin \& Braun (1996) as well as Braun (1998) and Ruszkiewicz-Michalska \& Wołczańska (2008). Study of micromorphological structures under the scanning electron microscope showed that the conidia are not just smooth but have sparsely verruculose, rough walls (Fig. 1D, E) and the observed conidiogenous scars (loci) have low, crenulate to sinuous edges and a small crater in their center (Fig. 1F, H), which distinguish this species from the genus Ramularia. The features of $N$. bidentis conform well with the current concept of the genus Neoramularia that is characterized by straight conidiophores with terminal, polyblastic, percurrent and sympodial conidiogenous cells, not thickened or darkened conidiogenous loci, solitary and catenate conidia (Videira et al., 2016). The studied fungus $N$. bidentis belongs to a group of Neoramularia species characterized by producing catenate conidia, such as N. esfandiarii (Petr.) U. Braun and N. phragmitis (Nagorny) U. Braun.

2. Ramularia crepidis Ellis \& Everh., Journal of Mycology 4(4-5): 46. 1888. - Ramularia eximia Bubák, Sitzungsberichte der Königlichen Böhmischen Gesellschaft der Wissenschaften 12: 18. 1903. (Fig. 2)

On living and fading leaves. Leaf spots on both sides of living leaves, at first orbicular or irregular, 1-2 $\mathrm{mm}$ across, greenish grey, small, scattered and without distinct margins; later becoming dry, angular, sometimes orbicular, scattered, developing along the small veins and limited by them, 3-5 mm, tan to light brown, the same lesions on lower surface of the leaf appearing as small diffuse dark greenish or brownish areas; sometimes surrounded by a narrow, dark brown halo; when numerous leaf lesions causing irregular, mottled, pale yellowish brown necrotic patches with some darker areas, bearing greyish white caespituli on both sides of leaf. Mycelium immersed, hyphae colorless, septate, 2-3 $\mu \mathrm{m}$ wide, forming stromatic, colorless, small, subglobose hyphal aggregations in leaf tissues, 16-25 $\mu \mathrm{m}$ diam., aggregations subepidermal or partly superficial, gradually widen the leaf stomata apart and slightly protruding, giving rise to upward-projecting conidiophores in small to large tufts, loose or dense, mainly hypophyllous. Conidiophores colorless, subcylindrical to cylindrical, 

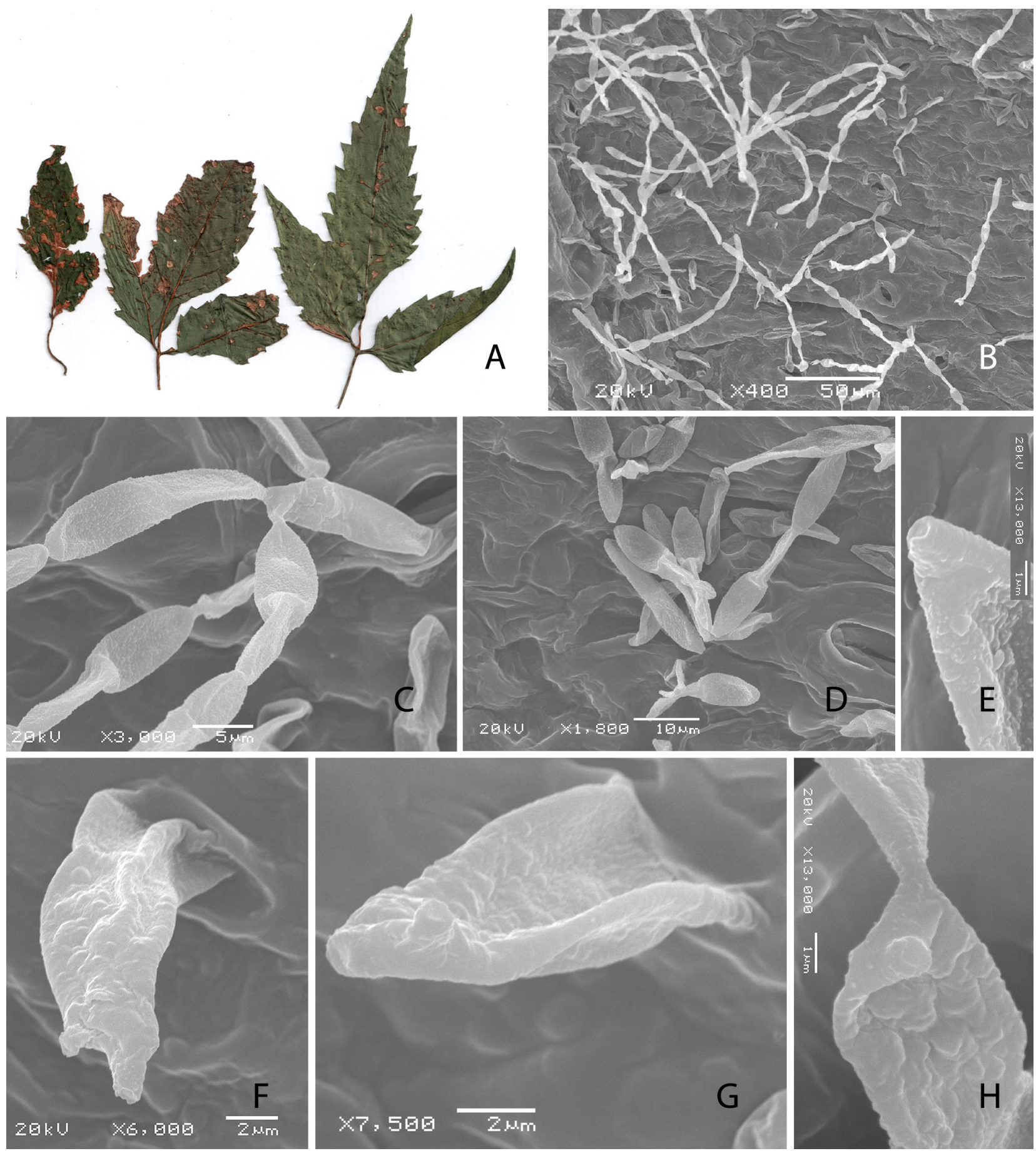

Fig. 1. Neoramularia bidentis.

Symptoms on leaves (DM). A: lesions of $N$. bidentis on the upper and lower leaf surfaces of Bidens frondosa. Scanning electron microscope images. B: general view of conidiophores and conidia in chains on the leaf; $\mathrm{C}$ : conidiophores with attached and seceded conidia; D: conidia; E: detail of a hilum (scar) on a sparsely granulate conidium; F, G: short conidiophores with conidiogenous loci (scars); H: conidiogenous cell with attached conidium (conidial base visible at the top) in process of seceding and an older projected conidiogenous locus (scar) 

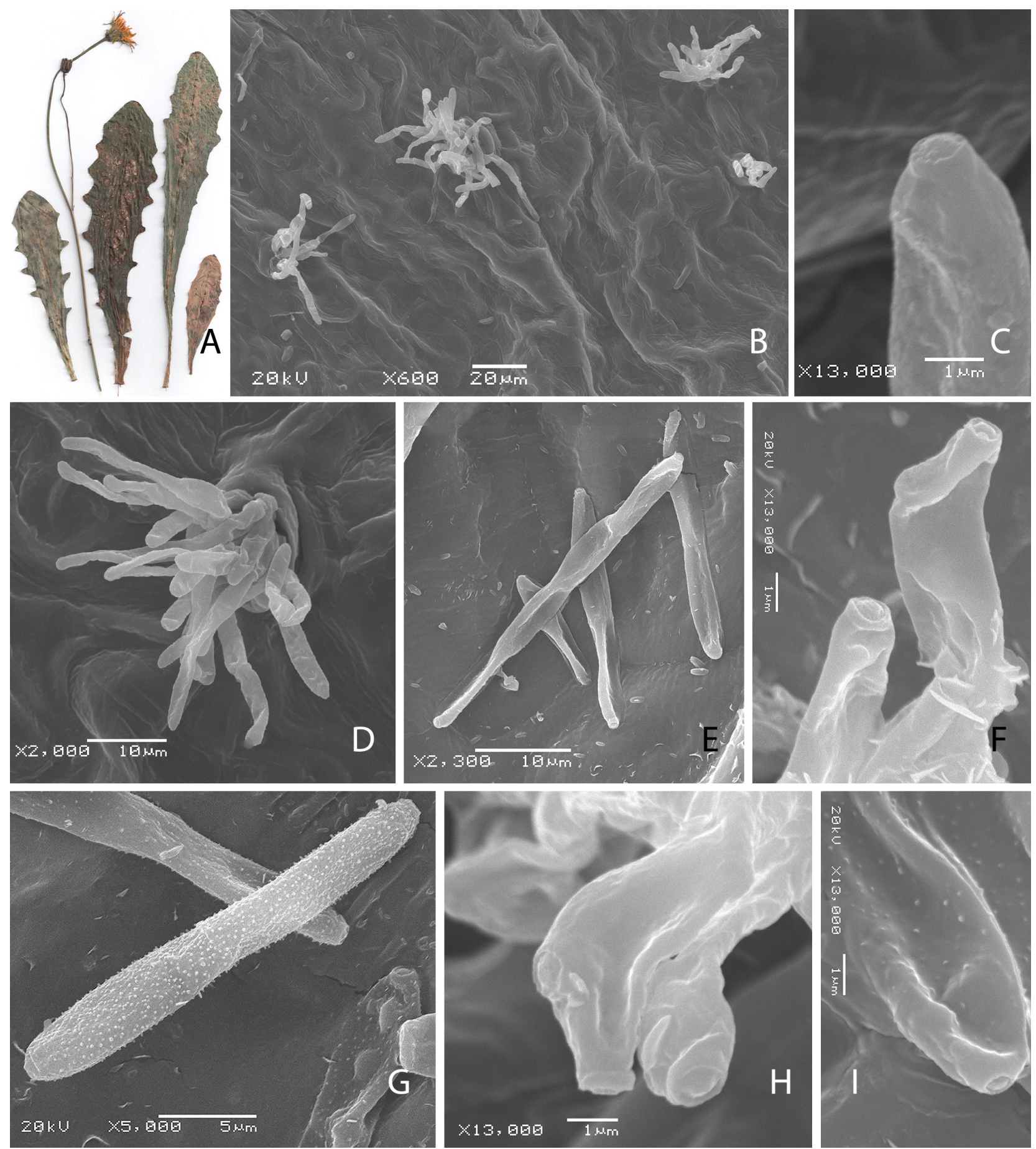

Fig. 2. Ramularia crepidis.

Symptoms on leaves (DM). A: lesions of $R$. crepidis on the upper and lower leaf surfaces of Crepis tectorum. Scanning electron microscope images. B: general view of conidiophores with a few conidia on the leaf; C: conidiogenous cell showing a scar of a conidiogenous locus; D: conidiophore fascicle on the lower surface of the leaf emerging through a leaf stoma; E: septate older conidia with sparse and weak ornamentation of the cell walls; F, H: apexes of conidiogenous cells with sympodial proliferations and conidiogenous loci, showing scars with low, smooth periclinal rims; G: muricate 2-celled conidium showing two terminal hila (scars); I: detail of a hilum (scar) on an ornamented conidium

Украӥнський ботанічний журнал, 2020, 77(1) 
straight or sinuous, without or with a few geniculations in the apical part, $(10-) 15-40 \times 2.5-4.0(-4.5) \mu \mathrm{m}$, smooth, simple, with up to 2 septa. Conidiogenous cells terminal, colorless, holoblastic, with one or a small number of sympodial proliferations and conspicuous conidiogenous loci (scars), thickened, pigmented (viewed under the LM), 0.8-1.2 $\mu \mathrm{m}$ diam., each with a low, smooth periclinal rim, $0.1-0.2 \mu \mathrm{m}$ wide, where the walls of the conidiogenous cell and conidium are joined prior to secession, with a slightly sinuous edge, and a slightly bulging dome in the central part of delimiting septum, with a barely noticeable crater between the periclinal rim and dome; older scars with a flatter central dome (viewed under the SEM). Conidia colorless, single or catenate, in simple, short chains, produced holoblastically; individual conidia ovate-oblong, fusiform-ellipsoid to fusiformcylindrical, $(8-) 11-23(-33) \times(3.0-) 3.5-4.5 \mu \mathrm{m}$, smooth or verrucose to sometimes delicately echinulate (viewed under the LM) and sparsely muricate to granulate with projections $0.1-0.3 \mu \mathrm{m}$ long and $0.1-0.2 \mu \mathrm{m}$ wide, older and longer conidia sometimes smooth (viewed under the SEM); unicellular or 1(3)-septate, sometimes narrower at the septa, cells not differing in size or apical cell smaller than the basal ones; ends rounded or sometimes basal end tapered and truncate, apical end rounded and slightly attenuated; conidial hila (scars) pointed, thicker, darker, raised to $0.1-0.2 \mu \mathrm{m}$ (viewed under the SEM).

Distribution in Ukraine. On leaves of Crepis tectorum L.: Volyn Region, Liubeshiv District, Prypyat'Stokhid National Nature Park, between Buchyn and Selisok villages, $51^{\circ} 47^{\prime} \mathrm{N}, 25^{\circ} 33^{\prime} \mathrm{E}$, Buchyna wood plot, slash in Pinus sylvestris L. forest, August 15, 2018, T.V. Andrianova; KW-M71184. - Sumy Region, Lebedyn District, Ukrainian Steppe Nature Reserve, Mykhailivska Tsilyna department, September 7, 1954, S.F. Morochkovsky; KW-M71177 (Morochkovsky, 1958).

General list of host plants. Crepis acuminata Nutt., C. biennis Lapeyr., C. foetida L., C. foetida subsp. rhoeadifolia (M.Bieb.) Čelak., C. mollis (Jacq.) Asch., C. pannonica (Jacq.) K. Koch. (also as C. rigida Waldst. \& Kit.), C. runcinata (E.James) Torr. \& A.Gray (type host), C. setosa Haller f., C. sibirica L., C. tectorum L., C. viscidula Froel. (Asteraceae).

General geographical distribution. Asia: Armenia, Azerbaijan, Georgia, Kazakhstan, Kyrgyzstan, Russia (Far East), Turkmenistan, Uzbekistan. Europe: Belgium, Bulgaria, Italy, Montenegro, Poland, Romania, Ukraine. North America: USA (New Mexico, Utah).
Notes. Second report for Ukraine.

This species is a typical hemibiotroph causing small leaf spots and then developing diffuse necrotic lesions, finally leading to leaf fading and withering. It was first described from New Mexico (USA) as Ramularia crepidis (Ellis, Everhart, 1888) and later under the synonymous name $R$. eximia from Montenegro (Bubák, 1903). In Europe, this species occurs in central and southern part of the continent (Braun, 1998; Mułenko et al., 2008), although it has been collected rather rare. This fungus may undoubtedly also survive under dry and hot climatic conditions in central Asia and it was recorded from the south of eastern Russia as well (Domashova, 1960; Shvartsman et al., 1973; Osipyan, 1975; Nakhutsrishvili, 1986; Koshkelova, 1977). Ramularia crepidis was observed only once in Ukraine, in the steppe zone, during early autumn of 1954 (Morochkovsky, 1958) without any additional reports since then. The present collection of this species in summer 2018 is the second one from Ukraine and the first one from Western Polissya on the same host plant, Crepis tectorum. The sultry summers and mild winters of the last decade may have resulted in an increase in distribution of $R$. crepidis in the northern part of Ukraine and possibly facilitated infections.

The new Ukrainian samples are characterized by narrower conidia, 3.5-4.5 $\mu \mathrm{m}$ wide, compared to the original description of $R$. crepidis based on material from New Mexico, USA, providing a conidial size of 12-35 $\times$ 5.0-6.0(-8.0) $\mu \mathrm{m}$ (Ellis, Everhart, 1888). Modern reviews of this species, based on collections from various geographical locations, indicate wider range of the conidial size, viz., $(10-) 15-45(-70) \times 3.0-8.0 \mu \mathrm{m}$ (Braun, 1998). Similarly, the conidia of $R$. crepidis from different locations in Armenia and Kyrgyzstan tended to be narrower, viz., 3.0-5.0 $\mu \mathrm{m}$ (Osipyan, 1975) and 4.0-5.0 $\mu \mathrm{m}$ (Domashova, 1960), respectively. At the same time, specimens of $R$. crepidis collected in Ukraine clearly differ by wider conidia from $R$. inaequalis (Preuss) U. Braun known on plant species of various genera of Asteraceae.

Studies of micromorphological structures of this fungus by the methods of scanning electron microscopy revealed the presence of sparsely muricate to granulate conidial walls, becoming smooth with ageing and the presence of characteristic (ramularioid) conidiogenous loci (material collected in Ukrane, KW-M71177, KW-M71184). Observed scars on conidiogenous cells are composed of a low periclinal rim and a minutely projected central dome delimited by a barely noticeable crater (Fig. 2F, H). These features of $R$. crepidis conform 
well to the current concept of the genus Ramularia (Braun, 1998; Kirschner, 2009; Videira et al., 2016).

3. Ramularia gnaphalii (P. Syd.) Karak., in Vasil'ievskiy N.I., Karakulin B.P., Fungi Imperfecti Parasitici. Hyphomycetes 1: 73. 1937. - Ovularia gnaphalii P. Syd., Hedwigia 38: 140. 1899. - Ramularia kabatiana Bubák, in Vestergren J.T.C., Botaniska Notiser 170. 1902. (Fig.3)

On living and withering leaves. Leaf spots at first orbicular or angular, irregular, 1-2 mm across, yellowish to hazel, small, scattered and without distinct margins, closer to leaf edges; developed spots dry, orbicular to irregular, scattered along the central veins, 3-4(-6) mm, tan to brown, sometimes light reddish brown, slightly pressed in the centers of initially infected tissue, with an indistinct reddish brown halo, delimitation from the healthy tissue not clearly visible; the same lesions on lower surfaces of the leaf sometimes paler; small leaf lesions becoming confluent when numerous, resulting in irregular reddish brown to brown areas on the leaf; lesions bearing greyish white to greyish pink caespituli, mainly, mainly hypophyllous. Mycelium immersed, hyphae colorless, septate, 1-3 $\mu \mathrm{m}$ wide, forming stromatic, colorless, subglobose hyphal aggregations in the leaf tissues under the stomata, (15-)20-35 $\mu \mathrm{m}$ diam., the aggregations gradually widening leaf stomata apart and emerging through the stomata, bearing small to large fascicles of projecting conidiophores, mainly hypophyllous. Conidiophores colorless, cylindrical, variously oriented, $20-60(-70) \times 3.0-3.5(-4.0) \mu \mathrm{m}$, smooth, straight or flexuous, geniculate in the apical part, unbranched, with a few septa. Conidiogenous cells terminal or intercalary, colorless, holoblastic, with one or a small number of sympodial proliferations, conidiogenous loci (scars) thickened, pigmented, distinctly prominent (viewed under the LM), 0.9-1.2 $\mu \mathrm{m}$ diam., each with a periclinal rim, less than $0.1 \mu \mathrm{m}$ wide and raised up to $0.3 \mu \mathrm{m}$ high at the point of attachment of the conidium, where the walls of the conidiogenous cell and conidium are joined prior to secession, with a slightly crenulated edge, and a bulging conical central dome formed at the delimiting septum, up to $0.2 \mu \mathrm{m}$ over the rim and tending to flatten in a central part, sometimes slightly granulated at the periphery, with a noticeable, deep crater between the periclinal rim and dome (viewed under the SEM). Conidia colorless, single or catenate, chains short, produced holoblastically; individual conidia ovate-oblong to obpyriform, ellipsoidal, subcylindrical or cylindrical, 9-16(-22) × 4.5-5.5(-6.5) $\mu \mathrm{m}$, echinulate or verruculose (viewed under the LM); muricate to densely spinulose with projections $0.2-0.3 \mu \mathrm{m}$ long and $0.1-$ $0.2 \mu \mathrm{m}$ wide (viewed under the SEM), younger single conidia with dense, digitate wall projections up to $0.6 \mu \mathrm{m}$ long; usually unicellular or 1-septate, not narrower at the septa, apical and basal cells of similar size; ends rounded or apex rounded, base tapered and truncate; hila (conidial scars) pointed, thickened, darkened, raised, $0.1-0.3 \mu \mathrm{m}$ high, with bulging central part (viewed under the SEM).

Distribution in Ukraine. On leaves of Omalotheca sylvatica (L.) Sch.Bip. \& F.W.Schultz (Gnaphalium sylvaticum L.): Kyiv Region, Fastiv District, Motovyliv Slobodka village, mixed forest of Quercus robur L. and Pinus sylvestris L., August 14, 1958, S.F. Morochkovsky; KW-M71178. - On leaves of G. uliginosum L.: Kyiv Region, Brovary District, Pogreby village, forest, July 22, 1973, Z.G. Lavitska; KW-M71186. - On living leaves of Laphangium luteoalbum (L.) Tsvelev: Volyn Region, Liubeshiv District, Prypyat'-Stokhid National Nature Park, Liubyaz' village, $51^{\circ} 50^{\prime} \mathrm{N}, 25^{\circ} 27^{\prime}$, Pinus sylvestris L. forest, near Liubyaz' Lake, August 13, 2018, T.V. Andrianova; KW-M71187.

General list of host plants. Gnaphalium sensu lato: $G$. norvegicum Gunnerus, G. rossicum Kirp., G. sylvaticum L. (type host; also as G. caucasicum Sommier \& Levier), G. uliginosum L., Laphangium luteoalbum (L.) Tsvelev (Asteraceae).

General geographical distribution. Asia: China, Georgia, Kazakhstan, Russia (Far East). Europe: Czech Republic, Denmark, France, Hungary, Germany, Iceland, Latvia, Poland, Romania, Russia, Sweden, Ukraine. North America: USA (Washington).

Notes. New host species and genus, rare fungus.

The fungus Ramularia gnaphalii is a pathogen of plants of the genus Gnaphalium s. 1. and it causes barely visible spots under the woolly leaf hairs, looking like manifestations of aging, withering and successive leaf dying. It should be noted that the report of $R$. gnaphalii on Laphangium luteoalbum (Syn. Gnaphalium luteoalbum L., Pseudognaphalium luteoalbum (L.) Hilliard \& B.L. Burtt) in Ukraine is just based on morphological studies of this fungus that have corresponding characters as the Ukrainian specimens of $R$. gnaphalii on Omalotheca sylvatica and Gnaphalium uliginosum in the last century. It is possible that this species has a much wider host range and can invade plants of other genera of the tribe Gnaphalieae. A recent study of the plant genus Gnaphalium s. 1. has revealed a high affinity of $L$. luteoalbum to some species 

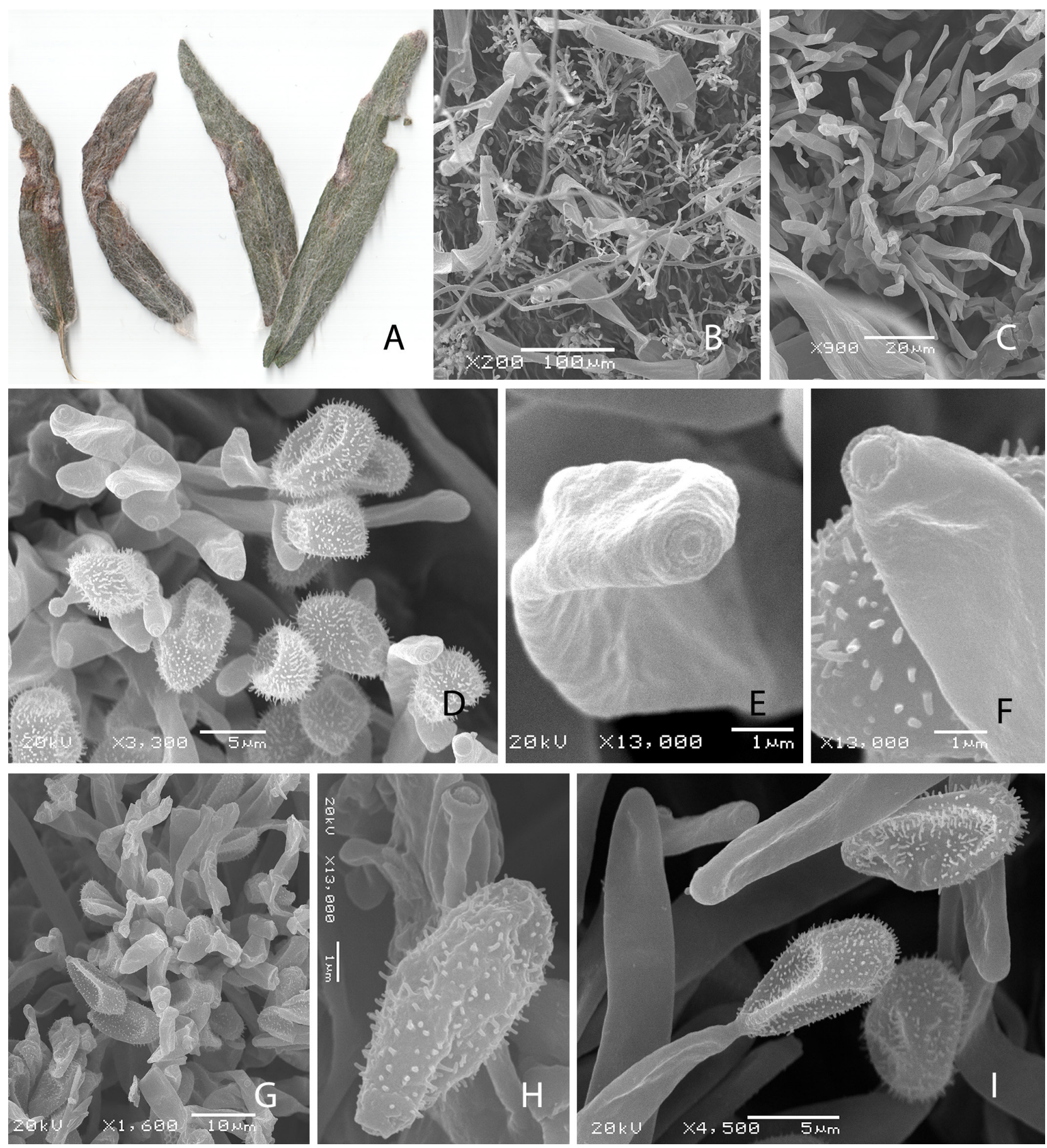

Fig. 3. Ramularia gnaphalii.

Symptoms on leaves (DM). A: sporulation of R. gnaphalii on living leaves of Laphangium luteoalbum. Scanning electron microscope images. B: caespituli with conidia on a leaf lesion; C: conidiophore fascicle with conidia on the lower surface of the leaf, emerging through a stoma; D: apical part of a conidiophore fascicle showing conidiogenous cells and densely ornamented conidia; E, F: conidiogenous cell apexes with proliferation and conidiogenous loci (scars) having slightly crenulated rims and bulging central domes; G: general view of conidiophores and conidia on the leaf of Omalotheca sylvatica (KW-M71178); H: apex of a conidiogenous cell with conidiogenous locus and ornamented conidium with a basal hilum (scar) on a leaf of G. uliginosum (KW-M71186); I: view of a conidium attached to but almost seceded from its conidiogenous cell, seceded conidia and conidiogenous cells on a leaf of L. luteoalbum 
of Pseudognaphalium Kirp. and Helichrysum Mill., and a more distant relationships with species of Gnaphalium (Acosta-Maindo, Galbany-Casals, 2018). The report of R. gnaphalii on Dahlia pinnata Cav. from China (Zhang, 2006) is rather controversial and in need of further studies although Ramularia species with wider ranges on different host genera from the family Asteraceae cannot be excluded.

The fungus $R$. gnaphalii occurs in forests of the temperate zone in Europe and was also reported from Asia and North America. In Ukraine, it has only been known from Kyiv Region since 1958 (Morochkovsky et al., 1971). The collection of this species in Volyn Region dated August 2018 is the third record from Ukraine and is the most recent one since 1973. It is the first report from Western Polissya.

The conidial wall ornamentation and the structure of conidiogenous loci of $R$. gnaphalii (Fig. 3E, F, H) agree with the current concept of the genus Ramularia (Braun, 1998; Kirschner, 2009; Videira et al., 2016).

4. Ramularia lysimachiae Thüm., Fungi austriaci exsiccati Cent. 12: no. 1177. 1874. - Cylindrosporium lysimachiae (Thüm.) J. Schröt., Kryptogamen-Flora von Schlesien 3(2): 492. 1897 [1908]. - Ramularia lysimachiarum Lindr., Acta Societatis pro Fauna et Flora Fennica 23(3): 28. 1902. - Ramularia paulula Davis, Transactions of the Wisconsin Academy of Sciences, Arts and Letters 16, 2 (1): 762. 1909. (Fig. 4)

On living leaves. Leaf spots suborbicular, oblong or irregular, 3-4 $\mathrm{mm}$ across, hazel or yellowish brown, scattered and without distinct margins; older lesions orbicular to irregular, scattered, limited by the central leaf vein, $3-5(-8) \mathrm{mm}$, bright tan to light brown, with indistinct, thin, brown margins, without a halo, the same spots are paler on lower leaf surface, with a greyish tint, fuzzy, bearing clusters of hypophyllous conidiophores; leaf spots later becoming confluent, causing irregular, pale $\tan$ to greyish tan patches that cover about half of the leaf surface, bearing greyish white caespituli on both sides of the leaf. Mycelium immersed, hyphae colorless, septate, 2-3 $\mu \mathrm{m}$ wide, branched, forming stromatic, colorless, small, subglobose hyphal aggregations in the leaf tissues, 10-25 $\mu \mathrm{m}$ diam., subepidermal and epidermal, sometimes in the substomatal chambers, gradually slightly protruding and erumpent through the leaf cuticle or rupturing the leaf stomata apart and emerging strait, upward-projecting conidiophores, usually in small fascicles, dense to loose in apical part or forming synnemata which are mostly erect and straight, tightly joined at the base and in the middle, and free, slightly bent outwards at the apex. Conidiophores colorless, in clusters of 10-20, cylindrical, $(10-) 20-50(-60) \times(2.5-) 3.0-4.0 \mu \mathrm{m}$, smooth, straight or sinuous, geniculate in apical part, unbranched, thinwalled, unicellular or 1-2-septate, sometimes apical part sparsely spinulose near the conidiogenous loci (viewed under the SEM). Conidiogenous cells terminal, colorless, holoblastic, with one or few sympodial proliferations and conspicuous, thickened, darkened scars of conidiogenous loci (viewed under the LM), 1.2-1.4 $\mu$ m diam.; each scar with a periclinal rim, about $0.1 \mu \mathrm{m}$ wide and raised to $0.1-0.3 \mu \mathrm{m}$, where the walls of the conidiogenous cell and conidium were joined prior to secession, with a slightly sinuous to fine crenulated edge and granulated central dome rising up to $0.2 \mu \mathrm{m}$ over the rim edge and formed by minute bulging of the delimiting septum, granules up to $0.1 \mu \mathrm{m}$ diam., with a minute crater between the periclinal rim and dome (viewed under the SEM). Conidia colorless, formed singly or catenate, chains short, produced holoblastically; individual conidia ellipsoidal, fusiform to subcylindrical or cylindrical, (10) $15-25(-30) \times 3.0-4.0(-4.5) \mu \mathrm{m}$, verrucose to echinulate (viewed under the LM) and with muricate to spinulose projections, $0.15-0.30 \mu \mathrm{m}$ long and up to $0.20 \mu \mathrm{m}$ wide (viewed under the SEM), unicellular or 1-septate, not narrower at the septa, apical and basal cells of similar size; ends rounded and slightly attenuated, obtuse; hila (scars) pointed, thickened, darkened, raised up to $0 \cdot 3 \mu \mathrm{m}$ (viewed under the SEM).

Distribution in Ukraine. On leaves of Lysimachia punctata L.: Lviv Region, Stryi District, Pidhirtsi village, July 20, 1917, F. Petrak (Petrak, 1925). - On leaves of L. vulgaris L.: Crimea, Alushta town, forest, August 16, 1916, L. Garbowski (Garbowski, 1924). - Volyn Region, Shatsk District, Shatsk National Nature Park, environs of Shatsk town, Alnus glutinosa (L.) Gaertn. forest, July 04, 1998, T.V. Andrianova; KW-M71179; Melnyky village, Melnyky wood plot, marsh, July 08, 1998, T.V. Andrianova; KW-M71180; Melnyky village, Melnyky wood plot, meadow bog, near Pisochne lake, July 12, 1998, T.V. Andrianova; KW-M71181; environs of Shatsk town, A. glutinosa (L.) Gaertn. forest, near Lutsymer lake, July 20, 1998, T.V. Andrianova; KW-M71182 (Andrianova, 1999). - Volyn Region, Liubeshiv District, Prypyat'-Stokhid National Nature Park, 51 ${ }^{\circ} 52^{\prime}, 25^{\circ} 38^{\prime}$, Svalovychy village, Svalovychy wood plot, mixed forest with Carpinus betulus L., August 14, 2018, T.V. Andrianova; KW-M71183. 

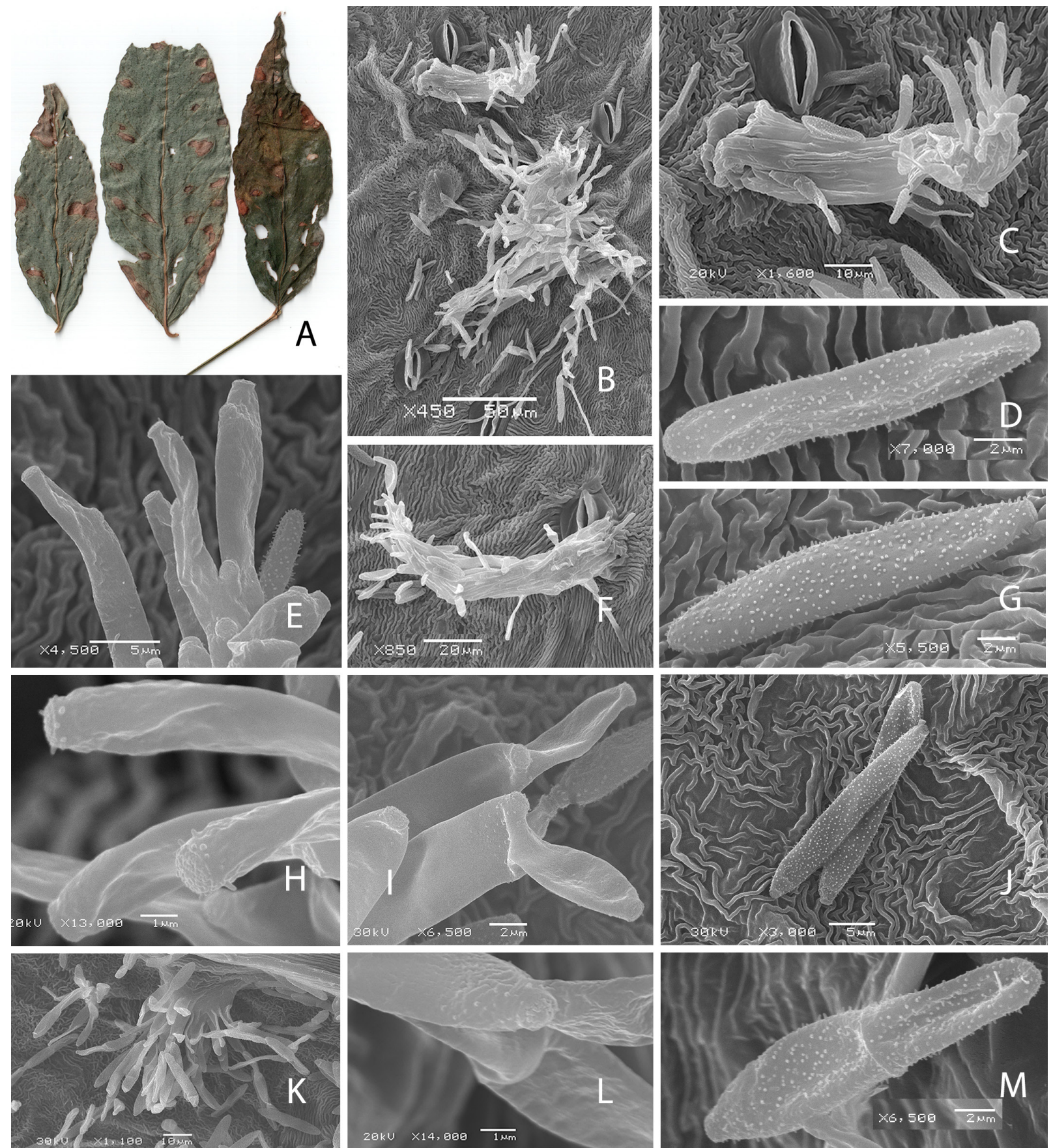

Fig. 4. Ramularia lysimachiae.

Symptoms on leaves (DM). A: lesions of $R$. lysimachiae on the lower and upper leaf surfaces of Lysimachia vulgaris. Scanning electron microscope images. B: general view of caespituli on a leaf; C, F: fascicles of conidiophores forming dense synnematous conidiomata and showing conidiogenous cells and conidia; D, G: conidia with muricate to spinulose projections; E: conidiogenous cells with sympodial proliferations and conidiogenous loci (scars); H: scars of conidiogenous loci with granulated central domes; I: details of conidiogenous loci (scars) on conidiogenous cells and a seceding conidium, from a leaf lesion of $L$. thyrsiflora collected in Finland (KW-M); J: muricate conidia from a leaf lesion of L. thyrsiflora collected in Finland (KW-M); K: conidiophore fascicle on the lower surface of a leaf, emerging from leaf vein (L. thyrsiflora, Finland, KW-M); L: conidiogenous cell showing a conidiogenous locus (scar) with a low periclinal rim from a leaf lesion on L. vulgaris in Russia (KW-M); M: muricate 2-celled conidium from a leaf lesion on L. vulgaris in Russia (KW-M) 
Additional specimens examined. On leaves of Lysimachia thyrsiflora L.: Finland, Pirkanmaa Region, Sastamala District (former Tyrvää), Eko village, July 07, 1961, L. \& H. Roivainen (Satakunta, Tyrvää, Eko; Plantae ex Herbarium University Helsingiensis); KW-M. - On leaves of L. vulgaris L.: Russia, Leningrad Region, Kirovsk District, environs of Otradnoe town, August 02, 1980, V.A. Melnik (E Sectione Cryptogamica Instututi Botanici Academiae Sc.URSS); KW-M.

General list of host plants. Lysimachia ciliata L. (also as Steironema ciliatum (L.) Raf.), L. clethroides Duby, L. lanceolata Walter, L. nemorum L., L. nummularia L., L. punctata L., L. terrestris (L.) Britton, Sterns \& Poggenb., L. thyrsiflora L. (type host), L. verticillata (Greene) Hand.-Mazz., L. vulgaris L. (Primulaceae).

General geographical distribution. Asia: Armenia, Georgia, Kazakhstan, Russia (Ural, Western Siberia). Europe: Austria, Belgium, Belarus, Bulgaria, Czech Republic, Denmark, Estonia, Finland, France, Hungary, Germany, Italy, Latvia, Lithuania, Moldova, Netherlands, Poland, Romania, Russia, Slovenia, Sweden, Switzerland, Ukraine, UK. North America: Canada, USA (Alaska, Iowa, New York, North Carolina, Texas, Wisconsin, Wyoming).

Notes. Relatively rare in Ukraine.

The monographers of the genus Ramularia regarded $R$. lysimachiarum as a synonym of $R$. lysimachiae (Vasil'evsky, Karakulin, 1937; Braun, 1998). The author of the present publication agrees with that view and also regards $R$. lysimachiarum as a synonym, although the names $R$. lysimachiae and $R$. lysimachiarum are treated as different species in the SpeciesFungorum database (www.speciesfungorum.org/Names/Names.asp, accessed 20 February 2019). The teleomorph of $R$. lysimachiae is unknown, although Mycosphaerella lysimachiae (Höhn.) Höhn. was previously assumed to belong to its life cycle (Tomilin, 1979), but this connection has not been proven.

Widespread in the Northern Hemisphere, R. lysimachiae, is a pathogen on leaves of Lysimachia L. New records of this species were registered from time to time from different countries (Sameva, 2004; Adamska, 2005; Mel'nik et al., 2007; Sarycheva et al., 2009; Khramtsov, Volosach, 2016). Last decade observations have indicated that $R$. lysimachiae is probably rare in Ukraine, at least in general, although locally abundant in Volyn Region (Western Polissya).

Microscopic examinations of the Ukrainian specimens from different years have revealed some specific characters of the fungal morphology. Synnematous aggregations of erect conidiophores, joined in the lower part and loose, splaying out in the apical portion (Fig. 4 B, C, F), were found alongside with typical Ramularia conidiophore fascicles (Fig. 4 B) in some specimens from Volyn Region, suggesting a higher morphological variability. Tufts or dense aggregations of conidiophores were previously reported for $R$. lysimachiarum from Russia (Vasil'evsky, Karakulin, 1937) which is treated as a synonym of $R$. lysimachiae. It should be noted that the specimens concerned were collected during hot, dry weather (August 2018), unusual for Volyn Region.

Further comparative examination of specimens on leaves of L. vulgaris from Ukraine and other collections of $R$. lysimachiae on the type host plant, L. thyrsiflora, in specimens from Finland (L. \& H. Roivainen, Plantae ex Herbarium University Helsingiensis; Fig. $4 \mathrm{I}-\mathrm{K}$ ), and on leaves of L. vulgaris, collected in the European part of Russia (V.A. Melnik, E Sectione Cryptogamica Instututi Botanici Academiae Sc.URSS; Fig. 4 L-M), has confirmed the identification of the fungus in the Ukrainian specimens as $R$. lysimachiae. All studied specimens are characterized by having corresponding sporulating structures, when being examined under a scanning electron microscope. Specimens had verrucose to echinulate conidial walls with muricate to spinulose projections, similar conidiogenous loci showing scars with a rough-granulated central dome and a minute crater between a finely crenulated periclinal rim and dome (Fig. 4 D-M). Conidiogenous loci of Phacellium episphaerium (Desm.) U. Braun and P. vossianum (Thum.) U. Braun differ, in comparison to ones of $R$. lysimachiae, and have smooth, wider periclinal rims, where the walls of the conidiogenous cells and conidia are joined prior to secession, and are defined by a noticeable crater between the periclinal rim and tapered dome (Andrianova, Minter, 2016, 2017).

In the current concept of the genus Ramularia an affinity of Ramularia species and some species of the synnematous genus Phacellium was assumed (Videira et al., 2016), at least tentatively, and a new phylogenetically congeneric synnematous species was described as $R$. trigonotidis Videira, H.D. Shin \& Crous. The features of the examined new collections on $L$. vulgaris from Ukraine fully comply with the current broad concept of the genus Ramularia and confirm the taxonomic position of $R$. lysimachiae in Ramularia. 


\section{Acknowledgements}

We are grateful to Vitalyi Sapsay, a former staff member of the M.G. Kholodny Institute of Botany of the National Academy of Sciences of Ukraine, for his technical assistance with scanning electron microscopy and PhD Mykhailo Khymyn, the Deputy Director of Prypyat'-Stokhid National Nature Park, for his support in sampling fungal material.

\section{References}

Acosta-Maindo A., Galbany-Casals M. 2018. Pseudognaphalium aldunateoides back in Gnaphalium (Compositae: Gnaphalieae). Collectanea Botanica, 37(e012): 1-27. https://doi.org/10.3989/collectbot.2018. v37.012

Adamska I. 2005. Fungi of the genus Ramularia of the Slowinski National Park. Acta Mycologica, 40: 203-221. https://doi.org/10.5586/am.2005.020

Andrianova T.V. 1999. Ukrainian Botanical Journal, 56(5): 466-478. [Андріанова Т.В. 1999. Фітотрофні мітоспорові гриби Шацького національного природного парку. Український ботанічний журнал, 56(5): 466-478].

Andrianova T.V., Minter D.W. 2016. Phacellium episphaerium. In: IMI Descriptions of Fungi and Bacteria. Wallingford, UK: CAB International, 207(2063): 1-5.

Andrianova T.V., Minter D.W. 2017. Phacellium vossianum. In: IMI Descriptions of Fungi and Bacteria. Wallingford, UK: CAB International, 214(2134): 1-4.

Braun U. 1998. A monograph of Cercosporella, Ramularia and allied genera (phytopathogenic Hyphomycetes), vol. 2. Eching bei Munchen: IHW-Verlag, 493 pp.

Bubák F. 1903. Ein beitrag zur pilzflora von Montenegro. Sitzungsberichte der Königlichen Böhmischen Gesellschaft der Wissenschaften, 12: 1-22.

Domashova A.A. 1960. Mikoflora Khrebta Terskyi Ala-Too Kirgizskoi SSR. Frunze: Publishing House of the Kyrghyz Academy of Sciences, 242 pp. [Домашова A.A. 1960. Микофлора Хребта Терский Ала-Тоо Киргизской ССР. Фрунзе: Изд-во АН КиргизССР, 242 с.].

Ellis J.B., Everhart B.M. 1888. New species of fungi from various localities. Journal of Mycology, 4(5): 44-46.

Farr D.F., Rossman A.Y. 2019. Fungal Databases, U.S. National Fungus Collections, ARS, USDA. Available at: https://nt.ars-grin.gov/fungaldatabases/ (Accessed 24 January 2019).

Garbowski L. 1924. Les micromycètes de la Crimée et des districts limitrophes de la Russie méridionale en considération spéciale des parasites des arbres et des arbrisseaux fruitiers. Bulletin Trimestriel de la Société Mycologique de France, 39(4): 227-259.

Guatimosim E., Pinto H.J., Pereira O.L., Fuga C.A.G., Vieira B.S., Barreto R.W. 2015. Pathogenic mycobiota of the weeds Bidens pilosa and Bidens subalternans. Tropical
Plant Pathology, 40: 298-317. https://doi.org/10.1007/ s40858-015-0040-x

Index Fungorum. 2019. Available at: http://www. indexfungorum.org/names/Names.asp (Accessed 04 February 2019).

Khramtsov A.K., Volosach M.N. 2016. Ecologicheskyi Vestnik, 2(36): 40-48. [Храмцов А.К., Волосач М.Н. 2016. Фитопатогенные микромицеты Чашникского района Беларуси. Экологический вестник, 2(36): 40-48].

Kim J.D., Shin H.D. 1999. Taxonomic studies on Cercospora and allied genera in Korea (VI). Korean Journal of Mycology, 27(1): 54-62.

Kirshner R. 2009. Cercosporella and Ramularia. Mycologia, 101(1): 110-119. https://doi.org/10.3852/07-038

Koshkelova E.N. 1977. Micromycety Yuzhnogo Turkmenistana, part 1. Ashkhabad: Ylym Publishing, 328 pp. [Кошкелова Е.Н. 1977. Микромицеты Южного Туркменистана, часть 1. Ашхабад: Изд-во Ылым, 328 c.].

Mel'nik V.A., Popov E.S., Shabunin D.A. 2007. Mikologia $i$ Fitopatologia, 41(6): 515-525. [Мельник В.А., Попов Е.С., Шабунин Д.А. 2007. Материалы к изучению микобиоты Новгородской и Псковской областей. І. Гифомицеты. Микология и фитопатология, 41(6): 515-525].

Morochkovsky S.F. 1958. Ukrainian Botanical Journal, 15(3): 74-82. [Морочковський С.Ф. 1958. Матеріали до мікофлори заповідника Михайлівська цілина. Украӥнський ботанічний журнал, 15(3): 74-82].

Morochkovsky S.F., Radzievsky G.G., Zerova M.Ya., Dudka I.O., Smitska M.F., Rozhenko G.L. 1971. Vyznachnyk Grybiv Ukrainy. Nezaversheni gryby, vol. 3. Kyiv: Naukova Dumka, 696 pp. [Морочковський С.Ф., Радзієвський Г.Г., Зерова М.Я., Дудка I.О., Сміцька М.Ф., Роженко, Г.Л. 1971. Визначник грибів України. Незавершені гриби, т. 3. Київ: Наукова думка, 696 c.].

Mułenko W., Majewski T., Ruszkiewicz-Michalska M. (eds.) 2008. A preliminary checklist of micromycetes in Poland. In: Biodiversity of Poland, vol. 9. Kraków: Polish Academy of Sciences, $752 \mathrm{pp}$.

MyCoPortal. 2019. Available at: http://mycoportal.org/portal/ index.php (Accessed 24 January 2019).

Nakhutsrishvili I.G. (ed.) 1986. Flora Sporovykh Rasteniy Gruzii (Conspect). Tbilisi: Metsniereba, 888 pp. [Нахуцришвили И.Г. 1986. Флора споровых растений Грузии (конспект). Тбилиси: Мецниереба, 888 с.].

Osipyan L.L. 1975. Mycoflora Armyanskoy SSR. Hyphomycetnye Griby, vol. 3. Yerevan: Yerevan University Publishing House, 643 pp. [Осипян Л.Л. 1975. Микофлора Армянской ССР. Гифальные грибы, т. 3. Ереван: Изд-во Ереванского университета, 643 с.].

Petrak F. 1925. Beiträge zur Pilzflora Südost-Galiziens und der Zentralkarpathen, Hedwigia, 65(6): 179-330.

Ruszkiewicz-Michalska M., Wołczańska A. 2008. The first report of Neoramularia bidentis from Europe. Mycotaxon, 106: 479-483. 
Sameva E.F. 2004. New records of anamorphic fungi from Bulgaria. Mycologia Balcanica, 1: 55-57.

Sarycheva L.A., Svetasheva T.Y., Bulgakov T.S., Popov E.S., Malysheva V.F. 2009. Mycobiota of Lipetskaya oblast. Voronezh: Publishing House of Lipetsk State University, 287 pр. [Сарычева Л.А., Светашева Т.Ю., Булгаков Т.С., Попов Е.С., Малышева В.Ф.2009. Микобиота Липеиякой области. Воронеж: Издательско-полиграфический центр Воронежского государственного университета, 287 c.].

Shin H.D., Braun U. 1996. Notes on Korean cercosporae and allied genera (1). Mycotaxon, 58: 157-166.

Shvartzman S.R., Vasyagina M.P., Byzova Z.M., Filimonova N.M. 1973. Flora Sporovyh Rasteniy Kazakhstana, vol. 8, part 1. Alma-Ata: Nauka Publishing House of Kazakh SSR, 527 pp. [Шварцман C.P., Васягина М.П., Бызова 3.М., Филимонова Н.М. 1973. Флора споровых растений Казахстана, т. 8, часть 1. Алма-Ата: Наука Казахской ССР, 527 с.].
Tomilin B.A. 1979. Opredelitel gribov roda Mycosphaerella Johans. Leningrad: Nauka, 319 pp. [Томилин Б.А. 1979. Определитель грибов рода Mycosphaerella Johans. Ленинград: Наука, 319 с.].

Vasil'evskiy N.I., Karakulin B.P. 1937. Fungi Imperfecti Parasitici. I. Hyphomycetes. Moscow; Leningrad: Publishing House of the USSR Academy of Sciences, 519 pp. [Васильевский Н.И., Каракулин Б.П. 1937. Паразитные Несовериенные Грибы. І. Гифомицетыл. Москва; Ленинград: Изд-во АН СССР, 519 с.].

Videira S.I.R., Groenewald J.Z., Braun U., Shin H.D., Crous P.W. 2016. All that glitters is not Ramularia. Studies in Mycology, 83: 49-163. https://doi.org/10.1016/j. simyco.2016.06.001

Zhang Z. 2006. Flora Fungorum Sinicorum. Botrytis, Ramularia, vol. 26. Beijing: Science Press, 277 pp.

Recommended for publication V.P. Heluta 